to fully regain its activity, put out a pseudopod and moved in the field, leaving behind it a group of the particles or granules. Only for a little while, however, did it move ; in a few moments it lost its animation, seemed to become transparent, and at last faded into one of those disks which seem to be merely the shells of once active forms. I did not see it move again.

This observation was carried on continuously during two hours and a half, and every stage watched most closely. I was at a loss what to call it, if not a clear case of conjugation and separation.

The most convincing proof to my mind that this was a proceeding which was for a purpose was given when, two nights after, this slide, which was laid carefully aside for future examination, was found to be full of young Amobce. They literally swarmed; I counted in the field at one time twenty-four of uniform size, while I have no hesitation in saying that there were between one and two hundred in the slide, which had before held but two. The wornout disk was recognized, and also what seemed to be the remains of the larger Amoba.-Proc. Acad. Nat. Sci. Philad., Oct. 26, 1886, p. 346 .

\title{
On the Byssal Organ of the Lameilibranchiata.
}

By M. Ludwig Reichel.

My researches upon the byssal organ have led me to the following results, which differ from previous statements.

From the observations of Réaumur and A. Müller it is generally regarded as proved that bivalve Mollusca which have once been attached by a byssus are thereby prevented from changing their place throughout their lives, unless they are torn away accidentally by external force. The animals can, however, temporarily regain their power of free movement, although not by tearing or separating the byssus-threads as the two naturalists referred to thought possible, but by throwing off the whole of the byssus, $i$. $e$. with stem and root, when the organ is replaced by a new formation. This casting of the byssus is a process exactly analogous to the change of skin in the Arthropoda. In Dreissence polymorpha such a change of the byssus takes place regularly at the commencement of the cold season. In summer the animals are seated close to the surface of the water, so that they are easily reached by the hand from the bank; towards the end of autumn, however, they retire into the deep water, leaving their byssus behind them.

As regards the formation of the byssus, it is almost universally regarded as the secretion of special glands. I cannot adopt this opinion, any more than that supported by von Nathusius-Königsborn, that the byssus grows forth out of the tissues of the body of the animal. The byssus rather originates as a cuticular formation, the stem with the roots in the byssal cavity and the threads in the pedal groove. Thus in those Lamellibranchiata which are provided with a byssus the underside of the foot is traversed by a rather deep longitudinal groove, which opens at the base of the foot into a cavity, the so-called byssal cavity. In the opinion of those who adopt the theory of secretion the foot and the walls of the byssal 
cavity are occupied by gland-cells which discharge their secretion into the groove, i.e. the cavity, and furnish the material for the formation of the byssus. No such gland-cells are present, howev r, as I shall demonstrate more in detail in my completed memoir.

The groove which traverses the foot shows two distinct parts, an outer one of simply fissure-like form, and an inner one with a crescentic transverse section. This is quite in open connexion with the fissure, and is to be regarded merely as the sudden dilatation of the fissure towards the two sides. By the approximation of the margins of the fissure it can be closed so as to form a complete canal, which is called the crescentic canal from the form of its transverse section. It is exclusively in this part of the groove that the byssal threads originate as a cuticular formation of the epithelium which lines the canal. This is not a vibratile epithelium like that which forms the surface of the fissure, the processes which are seated upon the epithelial cells of the canal are the byssal substance formed by them, but not vibratile cilia, for which they have hitherto been taken.

Two characters accentuate the distinction between the epithelium of the canal and the vibratile epithelium of the fissure. In the latter the cilia are seated upon a cell-membrane, which in transverse section is distinctly recognizable by a double contour. In the former, however, only a simple line appears beneath the processes, and this forms the boundary between the byssal substance and the epithelial cell. Further, each of these epithelial cells in the canal has only one process, while in the vibratile epithelium a number of cilia are seated upon each cell.

As already indicated a byssus consists of a stem with its roots, and byssal threads seated upon the stem.

According to the secretion-theory, threads are produced only when the stem is partially or completely developed, and they are attached or stuck to it. Further, a different mode of production from the threads is frequently ascribed to the stem, inasmuch as it is said to be formed by gland-cells which differ from those which are contained in the foot. This notion is, however, contradicted by observation. The stem and threads of the byssus originate in the same manner, simultaneously, and in immediate connexion with each other. This indeed is quite natural, for the crescentic canal opens into the byssal cavity, passing into it gradually, so that its wall passes into that of the cavity. Now if a cuticular formation occurs it will extend over the whole surface of the cavity and the groove, and in consequence the threads originating in the canal will be united with the formation in the cavity.

The casting-off of the byssus is connected with a retrogression of the byssal cavity. This, in its normal state, is divided at the bottom by a great many perpendicular septa, standing in the longitudinal direction of the animal, into so many chambers or secondary carities. At the casting of the byssus these septa are reduced. From the previously complicated byssal cavity is produced a simple cavity, showing only a few folds in its walls. The septa originate afresh only with the new formation of the byssus; their epithelium gives 
origin to the roots of the byssus, which, in the form of lamellæ, oocupy the chambers between these septa.-Zoologischer Anzeiger, N. 260, September 12, 1887, pp. 488-490.

\section{Ovo-viviparous Generation in Tropidonotus.}

Professor Heilprin presented the following communication, dated April 15, 1887, from Mr. H. C. Young, of the Philadelphia Custom House, referring to a water-snake shot by that gentleman some fourteen years ago, at a locality about three miles above Salem, N. J.:-

"Upon examining the snake (which was almost as thick as my forearm) I found it contained considerable of a bunch which I supposed to be something it had swallowed; but upon cutting it open I found it contained small snakes in a bag, each one in a separate division formed as it were by a twist in the bag. I took them out, and found there were thirty-three of them of different sizes, a number of the smaller ones having a portion of an egg attached to them, which they appeared to be absorbing, the larger ones having already absorbed theirs. I was then convinced that while the land-snakes lay eggs in the earth, to be hatched by the heat of the sun, the young of the water-snake are actually hatched in the belly of the mother."

Prof. Heilprin stated that the snakes had been presented by Mr. Young to the Academy, and on examination proved to be Tropidonotus sipedon. The case demonstrated beyond a question of doubt that the species was ovo-viviparous.-Proc. Acad. Nat. Sci. Philad., April 26, 1887, p. 121.

\section{Literature of the Fossil Ganoid, Semionotus.}

By A. SMrth Woodward.

The appearance of the new part of Dr. Zittel's admirable ' Handbuch der Palæontologie' has enabled me to discover Dr. Fraas's description of Semionotus Kapffi, for which I had long sought in vain while preparing the list of species published in the last number of the 'Annals' (p. 178). Both the description and figures will be found in the 'Württembergische Jahreshefte,' vol. xvii. (1861), p. 91, pl. i., and here are also made known two other Keuper forms, S. elongatus and S. serratus, which differ from the Brora Jurassic fossil, among other points, in the characters denoted by their respective specific names. Dr. Zittel likewise refers to some brief descriptions of Italian Jurassic species by Bellotti, in Stoppani's 'Studii geologici e paleontologici sulla Lombardia' (1859), none of which apparently agrees with the new Semionotus Joassi.

It may be well to point out, moreover, that in the figure of $S$. Joassi (suprì, Pl. VIII. fig. 1) the artist has unfortunately omitted to include some fragments of the anal fin, which indicate that this appendage originally possessed more rays than are now completely shown, thus having a longer base and extending somewhat further back towards the tail. 


\section{$2 \mathrm{BHL}$ Biodiversity Heritage Library}

Reichel, M Ludwig. 1887. "On the byssal organ of the Lamellibranchiata." The Annals and magazine of natural history; zoology, botany, and geology 20, 318-320. https://doi.org/10.1080/00222938709460065.

View This Item Online: https://www.biodiversitylibrary.org/item/95053

DOI: https://doi.org/10.1080/00222938709460065

Permalink: https://www.biodiversitylibrary.org/partpdf/68558

\section{Holding Institution}

Harvard University, Museum of Comparative Zoology, Ernst Mayr Library

\section{Sponsored by}

Harvard University, Museum of Comparative Zoology, Ernst Mayr Library

\section{Copyright \& Reuse}

Copyright Status: Public domain. The BHL considers that this work is no longer under copyright protection.

This document was created from content at the Biodiversity Heritage Library, the world's largest open access digital library for biodiversity literature and archives. Visit BHL at https://www.biodiversitylibrary.org. 